
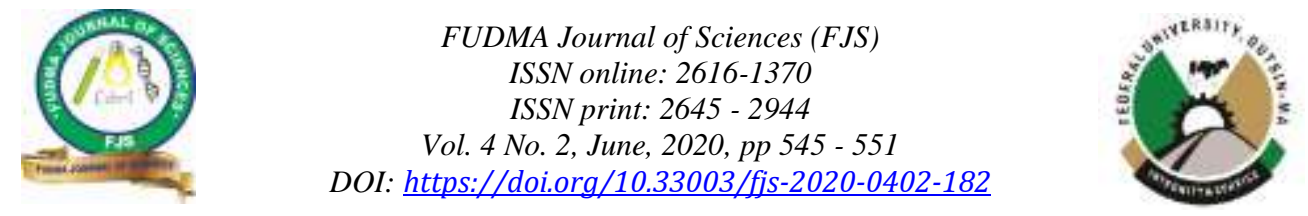

\title{
RURAL ROAD AND MARKETING OF AGRICULTURAL PRODUCE: A CASE STUDY OF KAJOLA LOCAL GOVERNMENT AREA OF OYO STATE, NIGERIA
}

\author{
${ }^{* 1}$ Alarima, C. I., ${ }^{2}$ Atata, S. N., ${ }^{1}$ Aromolaran, A. K., ${ }^{3}$ Ayansina, S. O., ${ }^{1}$ Awotunde, J. M., ${ }^{3}$ Fapojuwo, O. E. ${ }^{3}$ Ayinde, A. F. 0. \\ and ${ }^{1}$ Fashola, Y. A. \\ ${ }^{1}$ Department of Agricultural Extension and Rural Development, Federal University of Agriculture, Abeokuta, Nigeria; \\ ${ }^{2}$ Department of Communication and General Studies, Federal University of Agriculture, Abeokuta, Nigeria; \\ ${ }^{3}$ Department of Agricultural Administration, Federal University of Agriculture, Abeokuta, Nigeria \\ *Corresponding Author's email: corneliusalarima@yahoo.com 08036987418
}

\begin{abstract}
The transport system is fundamental to economic and social development of rural communities. The study examined the impact of road transportation system on the marketing of agricultural produce in Kajola local government area of Oyo state. Multi stage sampling technique was used to select one hundred and sixty (166) rural farmers for the study. Primary data were collected with the use of a pre-tested questionnaire and analyzed using descriptive and inferential statistics. Results revealed that $72.7 \%$ of the respondents were male, $69.5 \%$ were married with a mean age of 40.83 years. Also, $91.4 \%, 89.8 \%, 87.5 \%, 79.7 \%$ and $76.6 \%$, of the respondents produced maize, tomatoes, pepper, yam and cassava respectively while $21.9 \%$ produced cucumber. Furthermore, $60.2 \%$ of the farmers move their produce from the farm to the market through feeder roads using motorcycles due to the bad state of the roads. Respondents revealed that bad road networks bring about reduced quantity of farm produce leading to higher price. The result of the correlation analysis revealed that road transportation mode is significantly $(\mathrm{p}<0.05)$ related $(\mathrm{r}=0.317)$ to the marketing of agricultural produce. The study recommends the renovation of existing roads and construction of more rural feeder roads to link farmlands to the markets.
\end{abstract}

Keywords: Transportation, Marketing, Rural road, Kajola.

\section{INTRODUCTION}

Transportation is critical to the development of rural communities both in agricultural and non-agricultural sectors due to the role it plays on production processes in these areas. It is an integral part of agricultural development that must not be overlooked. It eases the movement of produce from the farm to various consumption destinations and aids the movement of inputs into farms. For any development to take place in the agricultural sector, transportation must be given the desired attention it deserves. Availability of transport facilities is an important investment that stimulates economic growth through increased accessibility and mobility (Tunde and Adeniyi, 2012). Accessibility and mobility determine the level of development in any given environment. The role of transport is very crucial and is a phase in the production process which is not complete until the commodity is in the hands of the final consumers Ajiboye and Afolayan (2009)

Transportation also influences the cost of commodity and the purchasing power of the consumers as it relates to the cost of production. The presence of an adequate, reliable and efficient transport system is a strategic factor in local economic development. A well developed transportation infrastructure provides adequate access to local communities, which in turn is a necessary condition for the efficient operation of manufacturing, retail, labour and housing market (Olubemehin, 2012).

Road transport system is a very important sub sector of transportation system. The importance of road transport infrastructure has been recognized as crucial to promoting growth and development. It is the most prevalent and commonly used mode of transportation for people, goods and services from the point of origin to the desired destination with the sole benefit of time and value chain addition (Olubemehin, 2012). This can be seen through its wide range of influence and increase productivity, income generation and better standard of living of the people. However, this role depends largely on the extent to which road infrastructure are adequately provided, distributed across board and maintained (Adefila and Bulus, 2014).

Effective transportation depends primarily on good and motorable road networks. The maintenance of road 
infrastructure also determines the effectiveness of the transportation system. Poor roads usually have undesirable effects not only on agricultural production but also on the entire socio-economic development of the rural areas since the rural economy depends largely on agriculture. Adequate and reliable rural roads improve rural productivity, enhance physical access, reduce poor people's vulnerability to shocks and stress and enable them to build their livelihood assets (Davies, 2000). Rural roads are not only important to agriculture, health and education; they also served as an integral and essential part for marketing agricultural produce. Previous studies conducted have also documented the impact of poor rural roads on the rural economy using various indices (Ipingbemi, 2001).

Kajola local government area is one of the local government areas in Oke Ogun region of Oyo state. The region is fondly referred to as the food basket of southwestern Nigeria. Agriculture remains the main occupation of the people in the local government. The local government is good for large scale production of a wide variety of agricultural produce which include yam, cassava, maize, vegetables, melon, guinea corn, pawpaw, water melon, plantain, banana, groundnut and cocoa. However, there is limited level of infrastructural and institutional development in the local government area. The poor road network is one of the mostly affected infrastructural facility militating against agricultural development in the local government area. This increases the cost of production because the farmers transport their produce out of the local government area at exorbitant rates. The perishable nature of agricultural produce also adds to the problems encountered by the farmers. In addressing these problems, there is need for good rural road network to reduce the transportation and selling cost/price as well as the flow of agricultural products from their origin to the final destination. This study therefore examined the effects of road transportation on the marketing of agricultural produce in Kajola Local government area of Oyo state. The specific objectives are to:

i. Identify the types of agricultural produce cultivated by the farmers.

ii. Identify the means of transporting agricultural produce.

iii. Examine the types and nature of roads in the study area.

iv. Determine the Farmers' perception of transportation on the marketing of agricultural produce in Kajola local government area.

v. Describe the extent to which road transportation services affect marketing of agricultural produce in the study area.

\section{RESEARCH METHODODOLOGY}

The study was carried out in Kajola Local Government Area (LGA) of Oyo State, Nigeria. Kajola has a land area of $609 \mathrm{~km}^{2}$ and a population of about 200,997 people (NPC, 2006). Kajola
L G A has its headquarter in Okeho. The area is located within the guinea savannah agro-climatic zone of Nigeria with an average annual rainfall of $800 \mathrm{~mm}$ spanning from March/April to October with the temperature varying between $25^{\circ} \mathrm{C}$ and $35^{\circ} \mathrm{C}$ and the relative humidity of $91 \%$. Farming is the major occupation of the people in the area in addition to other occupation like livestock rearing, handicraft and other small businesses. Crops mainly cultivated in the area include tubers (yam, cassava and sweet-potatoes), cereals (maize, guinea corn) and fruits (cashew, mango). Animals reared include small ruminants such as goat, sheep and guinea fowl.

Multistage sampling technique was used to select 128 farmers for this study.

Stage 1 involved random selection of 4 wards (Ayetoro, Kajola, Gbelekale and Ilaji/Iwere-Oke) out of the 12 wards in the Local Government Area, Stage 2 involved purposive selection of two villages each from the selected wards while the last stage was the purposive selection of 16 farmers from each of the selected villages given a total of 128 respondents.

Primary data were collected on the farmers' socio-economic characteristics, types of agricultural produce cultivated by the farmers, the means of transporting agricultural produce, the types and nature of roads in the study area and farmers' perception of transportation on the marketing of agricultural produce with the use of a pre-tested interview guide administered during the farming season. Frequency counts, percentages, means, standard deviations and Pearson Product Moment Correlation (PPMC) were used to analyse the data.

\section{RESULTS AND DISCUSSION}

\section{Socio-economic Characteristics of the Respondents}

Results in Table 1 shows that the mean age of the respondents was 40.83 years with $39.8 \%$ of the respondents within the age range of $41-50$ years, while $10.9 \%$ were less than 41 years. This implies that majority of the respondents in this study area were in their middle age and had physical strength to actively participate effectively in agriculture. Results further revealed that majority $(72.7 \%)$ of the respondents were male, while $27.3 \%$ were female. The higher percentage of the male respondents recorded could be attributed to the nature of the work done that is usually tedious and strenuous in addition to marketing and transportation of goods from one place to another. Majority (69.5\%) of the respondents were married and $9.4 \%$ were still single. This may be as a result of the nature of the farming work where there is always need for help of spouses or partners thereby conferring some level of responsibility. This was further confirmed by the report of Fakoya (2000) and Oladoja et al., (2008) who asserted that marriage confer some level of responsibility and commitment on individuals who were married. Also, $25.0 \%$ of the respondents had primary education and $16.5 \%$ had secondary education. The implication of this finding is that many of the respondents sampled were literate. Almost half $(44.6 \%)$ of the respondents were Christians while 
$35.9 \%$ were Muslims. Majority $(78.9 \%)$ of the sampled respondents were Yorubas, $11.7 \%$ were Hausas, $5.5 \%$ were Igedes and $3.9 \%$ were Igbos by tribe in the study area. This implies that the larger percentage of the respondents were Yorubas, which may be attributed to the location were the study is been carried out. The study further showed that $64.0 \%$ of the respondents cover between one to ten kilometers from their farms to the final consumer (market). This showed the need for good and motorable roads to enable the farmers get to the market on time and in good condition. Most of the crops produced by the respondents are perishable and hence the need for timely transportation. Long distance from the farm to the market with rough roads resulted in high loss of perishable crops leading to meager profit to the farmers.

Table 1: Distribution of Crop Farmers' Socio-economic Characteristics $(\mathbf{n}=128)$

\begin{tabular}{|c|c|c|c|}
\hline Variables & Frequency & Percentages (\%) & Mean/SD \\
\hline \multicolumn{4}{|l|}{ Sex } \\
\hline Male & 93 & 72.7 & \\
\hline Female & 35 & 27.3 & \\
\hline \multicolumn{4}{|l|}{ Age } \\
\hline Less than 41 & 14 & 10.9 & \\
\hline $41-50$ & 51 & 39.8 & $40.83 / 8.94$ \\
\hline $51-60$ & 48 & 37.5 & \\
\hline $61-75$ & 15 & 11.7 & \\
\hline \multicolumn{4}{|l|}{ Marital status } \\
\hline Single & 12 & 9.4 & \\
\hline Married & 71 & 55.5 & \\
\hline Divorced & 25 & 19.5 & \\
\hline Widowed & 20 & 15.6 & \\
\hline \multicolumn{4}{|l|}{ Educational level } \\
\hline No formal education & 19 & 14.8 & \\
\hline Primary education & 32 & 25.0 & \\
\hline Secondary education & 21 & 16.4 & \\
\hline Tertiary education & 10 & 7.8 & \\
\hline Vocational education & 32 & 25.0 & \\
\hline Adult education & 14 & 10.9 & \\
\hline \multicolumn{4}{|l|}{ Religion } \\
\hline Christianity & 57 & 44.6 & \\
\hline Islam & 46 & 35.9 & \\
\hline Traditional & 25 & 19.5 & \\
\hline \multicolumn{4}{|l|}{ Ethnicity } \\
\hline Yoruba & 101 & 78.9 & \\
\hline Igbo & 5 & 3.9 & \\
\hline Hausa & 15 & 11.7 & \\
\hline Egede & 7 & 5.5 & \\
\hline \multicolumn{4}{|c|}{ Distance from farm to Market } \\
\hline Less than $1 \mathrm{~km}$ & 26 & 20.31 & \\
\hline $1-5 \mathrm{~km}$ & 38 & 29.69 & \\
\hline $5-10 \mathrm{~km}$ & 44 & 34.38 & \\
\hline More than $10 \mathrm{~km}$ & 20 & 15.63 & \\
\hline
\end{tabular}

Source: Field survey, 2018

Types of Agricultural Produce Cultivated by the Crop Farmers

Results in Table 2 reveals that $79.7 \%$ of the respondents cultivated yam, $76.6 \%$ produced cassava and $36.7 \%$ produced potatoes in the study area. In cereals' production, $90.0 \%$ of the respondents were engaged in maize production, $33.6 \%$ cultivated guinea corn and $18.8 \%$ produced rice. Also, $47.0 \%$ and $41.1 \%$ of the respondents cultivated cashew and mango respectively. Most (89.8\%) of the respondents cultivate tomatoes, $87.5 \%$ produce pepper and $21.9 \%$ engage in production of cucumber in the study area. Rural areas serve as the base for the production of food and fiber, the major sources of capital formation for a country, and a principal market for domestic manufacturers (Olayiwola and Adeleye, 2005). The 
crops produced in this area clearly showed the level of the soil

fertility in this locality.

Table 2: Types of Agricultural Produce Cultivated by the Crop Farmers

\begin{tabular}{lll}
\hline Variables & Frequency & Percentages $(\%)$ \\
\hline Tubers & 102 & 79.7 \\
Yam & 98 & 76.6 \\
Cassava & 47 & 36.7 \\
Potatoes & & \\
Cereals & 117 & 91.4 \\
Maize & 24 & 18.8 \\
Rice & 43 & 33.6 \\
Guinea corn & & \\
Fruits & 60 & 46.9 \\
Cashew & 53 & 41.1 \\
Mango & & \\
Vegetables & 115 & 89.8 \\
Tomatoes & 28 & 21.9 \\
Cucumber & 112 & 87.5 \\
Pepper & & \\
\hline
\end{tabular}

Source: Field survey, 2018

\section{Means of Transportation of the Agricultural Produce}

Table 3 shows that majority (76.6\%) of the respondents sampled used motorbike popularly called Okada to transport their agricultural produce. The reason for the use of this mode of transportation is the poor condition of the roads from their farms to the towns and markets. Other means of transportation commonly used for transporting farm produce to the markets by the farmers were hired lorries $(64.1 \%)$, trekking $(63.3 \%)$ and pick-up vans (58.6). Road transport is the most predominant mode of transportation all over the world and this is a confirmation of the crucial role that transport plays in the socio-economic development of a nation (Ajiboye and Afolayan 2009).

Table 3: Various Means of Transportation

\begin{tabular}{lll}
\hline Various means of transportation & Frequency & Percentages (\%) \\
\hline Motorbikes & 98 & 76.6 \\
Wheel barrows & 20 & 15.6 \\
Trekking & 81 & 63.3 \\
Pick-up vans & 75 & 58.6 \\
Tri-cycles & 35 & 27.3 \\
Bus & 51 & 39.8 \\
Bicycles & 55 & 43.0 \\
Lorries & 82 & 64.1 \\
\hline
\end{tabular}

Source: Field survey, 2018

Nature of the Roads in the Study Area

Results in Table 4 show that $60.2 \%$ of farmers make their journey through feeder roads while $39.8 \%$ of their journey is done on footpath. This is because most of the farms in the rural areas are located far from standard motorable roads and are mainly linked with footpaths and tracks. Field observation also showed that the roads are characterized with unpaved surfaces, narrow width, and bush, filled with potholes, water logged, dirty and in deplorable states. Moreover, the poor state of the roads, made them nearly impassable during rainy seasons and passable during the dry season. In most cases, communal efforts are used to grade the roads during the dry season. The state of the roads thus affects the quality/freshness and the price/cost of farm produce especially vegetables and fruits. Also, the quality of life and well-being of farmers are equally affected. This arises from the fact that farmers spend their meager income on buying drugs and treating themselves for pains, headaches and general body ache due to long hours of trekking with load and poor quality of roads, loss of man hour/ time as the journey from and to the farm and market are longer and tedious.

Result in Table 4 further reveals that $30.3 \%$ of the respondents agrees that roads leading to their farms are graded, $24.2 \%$ reported that the roads have pot-holes and $20.2 \%$ said that roads to their farms are swampy/muddy at the time of this study. The implication of the above findings is that most roads used by crop farmers for transporting farm produce are not motorable. 
Interaction with transporters in the study area revealed that most of the roads in the rural areas especially the feeder roads are unsurfaced, narrow, bad and poorly drained and this prevents easy access to the market. Adedeji et al., (2014), reported that efficient and effective rural transportation serves as a panacea for movement of goods and services, dissemination of information and general promotion of the rural economy. The existence of accessible, acceptable and efficient transportation system is a pre-condition for linking remote farm areas located far from consumer centers with their target consumers (Taiwo and Kumi, 2013). The transport system is fundamental to the economic and social development in rural areas, and significant investment is required to meet the desired level of development.

Table 4: Nature of the Road

\begin{tabular}{ll}
\hline Types of farm access road & Percentages $(\%)$ \\
\hline Footpath & 39.8 \\
Feeder roads & 60.2 \\
\hline Condition/nature of the road & 24.2 \\
\hline Presence of pot-hole & 30.3 \\
Graded & 17.2 \\
Tarred & 20.2 \\
Swampy/Muddy & 8.1 \\
Hilly & \\
\hline
\end{tabular}

Source: Field survey, 2018

Respondents' Perception of the Effect of Transportation on Marketing of Agricultural Produce

Transportation is key to agricultural development all over the world especially in Nigeria. The role of transport system to economic and social development in rural areas cannot be glossed over and this calls for investment. Table 5 reveals that respondents perceived that road transport makes marketing of farm produce easier $(\chi=4.22)$. Ellis and Hines (2003) reported that transportation influences the cost of commodity consumed and the purchasing power of the consumers. This is because the nature of roads in which goods and services passes will determine the time and quality of goods reaching the consumers as well as the convenience/timeliness of delivery. The result of the study also revealed that respondents perceived that bad road network brings about reduction in quantity due to damage caused to farm produce during transportation $(\chi=3.84)$. Agricultural produce are mostly perishable, hence, there is need for proper handling especially from the point of production to the final consumer. This calls for prompt movement relying more on access roads. Most of the rural roads are in poor condition, and this has imposed significant cost on the national economy especially agricultural activities due to increased vehicle operating costs and travel times (Akintola, 2007).

Respondents also perceived that bad road leads to increased price of farm produce $(\chi=3.33)$. This is in accordance with Ellis and Hine (2003) who reported that road transportation influences the cost of commodity consumed and the purchasing power of the consumers. This is because bad roads will increase the time spent in getting the produce to the consumers while the quality will have been affected and the quantity reduced thereby leading to higher price. Paul et al. (2009) pointed out that the impacts of road infrastructure on agricultural output and productivity are particularly important in Sub-Saharan Africa for three reasons. First, the agricultural sector accounts for a large share of Gross Domestic Product (GDP) in most SubSaharan countries. Secondly, poverty is concentrated in rural areas. Finally, the relatively low levels of road infrastructure and long average travel times result in high transaction costs for sales of agricultural inputs and outputs, and this limits agricultural productivity and growth.

Table 5: Distribution of Effects of Transportation in the Marketing of Agricultural Produce $(\mathbf{n}=128)$

\begin{tabular}{|c|c|c|c|c|c|c|}
\hline Perception of Effects on marketing & $\mathbf{S A}(\%)$ & $\mathbf{A}(\%)$ & $\operatorname{SLA}(\%)$ & $\mathrm{D}(\%)$ & $\operatorname{SD}(\%)$ & Mean \\
\hline $\begin{array}{l}\text { Bad road network cause a reduction in freshness of the } \\
\text { products on getting to the market }\end{array}$ & $27(21.1)$ & $23(18.0)$ & $6(4.7)$ & $38(29.7)$ & $34(26.6)$ & 2.77 \\
\hline $\begin{array}{l}\text { Bad road network cause a slight change in the initial } \\
\text { colour of farm produce }\end{array}$ & 14(10.9) & $22(17.2)$ & $8(6.3)$ & $47(36.7)$ & $37(28.9)$ & 2.45 \\
\hline Bad road leads to an increase in price of farm produce & $26(20.3)$ & $31(24.2)$ & $39(30.5)$ & 23(18.0) & $9(7.0)$ & 3.33 \\
\hline $\begin{array}{l}\text { The cost of transporting farm produce by road is high in } \\
\text { my area }\end{array}$ & $8(6.3)$ & $32(25.0)$ & $55(43.0)$ & $20(15.6)$ & $13(10.2)$ & 3.02 \\
\hline
\end{tabular}


transportation.

Road transport makes marketing of farm produce easier. $\quad$ 56(43.8)

$54(42.2)$

$9(7.0)$

$8(6.3)$

$1(0.8)$

4.22

Source: Field survey, 2018

Relationship between Transportation Mode and Respondents' Perceived Effects of Marketing on Agricultural Produce

Result of correlation analysis in Table 6 indicates that there is significant relationship $(\mathrm{p}<0.05)$ between road transportation mode and perceived effect of marketing on agricultural produce $(r=0.317)$ in the study area. This indicates that mode of transportation influences the marketing of agricultural produce in the study area. Therefore, nature of roads is a major factor that affects cost of marketing farm produce as it would determine whether the products will be of good quality and get to the consumers in due time. As reported by (Tunde and Adeniyi (2012) road transportation affects the basic function of production, distribution, marketing and consumption in many ways especially the cost of commodity consumed and the purchasing power of the consumers. Transport affects agricultural marketing because it is the only means by which farmers can move their produce to the market (Tunde and Adeniyi 2012). The finding of the study also agrees with Tunde and Adeniyi (2012) who reported that road transport has a significant impact on distribution and marketing of agricultural produce in Ilorin, Nigeria. Ajiboye (1994) observed that poor marketing of food stuff resulting in inadequate supply and high cost is as a result of inefficient transportation and distribution. Development of rural areas depends very much on good road transportation facilities in that it enables the farmers and traders to transport their farm input and output from/to the urban areas. Poor transportation in the rural areas has resulted in low productivity, low income, a fall in the standard of living of rural residents and high rate of poverty (Tunde and Adeniyi 2012). The movement of various agricultural products from the rural areas is one of the most vital factors for marketing of products in the cities, which are essential for survival. Without a good transportation pattern, most agricultural products will not reach the areas of need at the appropriate time. The bad conditions of the road affect cost of transportation of agricultural produce which in turn affect the rural farmers' income (Tunde and Adeniyi, 2012). Transport plays a significant role in the structure of food production and marketing, therefore, easy transport to the market can make all the difference in the level of rural incomes (Ajiboye and Afolayan, 2009).

Table 6: Correlation result showing relationship between road transportation mode and marketing of agricultural produce.

\begin{tabular}{|l|l|l|l|}
\hline Variables & r-value & p-value & Decision \\
\hline $\begin{array}{l}\text { Transportation mode and } \\
\text { marketing of agricultural } \\
\text { produce }\end{array}$ & 0.317 & 0.001 & S \\
\hline
\end{tabular}

Source: Field survey, 2018

\section{CONCLUSION AND RECOMMENDATIONS}

The study concluded that mode of transportation influences the cost, prices, quality, quantity and marketing of agricultural produce in the study area. The study recommends the renovation of existing roads and construction of more rural feeder roads to link farmlands to the markets by the local government authority. In addition, communal efforts should be mobilized by the farmers to constantly renovate the existing rural roads to ameliorate the difficulties of the farmers and improved marketing of their farm produce.

\section{REFERENCES}

Adedeji, O. A., Olafiaji, E. M., Omole, F. K., Olanibi, J. A., and Lukman, Y. (2014). An assessment of the impact of road transport on rural development: A case study of obokun local government area of Osun State, Nigeria. British Journal of Environmental Sciences 2(1): 34-48.

Adefila, J. O. and Bulus J. S. (2014). The study of rural infrastructure facilities in Kajuru area, Kaduna state Nigeria. A spatial analysis or planning. International Journal of Humanities and Social Science, 4(2): 286-295

Ajiboye, A. O (1994). Rural accessibility and transportation problems. A case study of Ijebu North Local Governemnt Area,Ogun State. Unpublished PGD in Transport Thesis, Department of Geography and Regional Planning, Ogun State University, Ago-Iwoye.

Ajiboye, A. O. and Afolayan, O. (2009). The impact of transportation on agricultural production in a developing country: a case of kolanut production in Nigeria. International Journal of Agricultural Economics \& Rural Development, 2(2): 49-57.

Akintola, S. R. (2007). Coping with infrastructural deprivation through collective action among rural people in Nigeria. Nordic Journal of African Studies, 16 (1): 30- 46.

Ellis, S. and Hine, J. (2003). Agricultural marketing and access to transport services. TRL Limited, World Bank. 
Fakoya, E. O. (2000). Farmers' use of sustainable land management practices in Ondo state, Nigeria. Unpublished PhD. Thesis, Department of Agricultural Extension and Rural Development, University of Ibadan,160p.

Ipingbemi, I. (2001). Exploring labour- based approach for rural road maintenance in Nigeria. Journal of Social Sciences, 17(2): 103-111.

National Planning Commission. (2006). Nigeria's Vision 20:2020, Report of the Vision 2020 National Technical Working Group on Employment

Oladoja, M. A., Adedoyin, S. F. and Adeokun, O. A. (2008). Training needs of fisher folks on fishing technology. Journal of Food, Agriculture, Environment Science and Technology, 6(1): 95-98.

Olayiwola, L. M. and Adeleye, O. A. (2005). Rural infrastructural development in Nigeria between 1960-1990: Problems and challenges. Journal of Social Science, 11 (2): 9196.
Olubemehin, O. O. (2012). Road transportation as a lifeline of the economy in western Nigeria, 1920 to 1952. African Journal of History and Culture, 4(3): 33-45.

Paul, D., Hyoung-Gun.,W., Liang, Y. and Emily, S. (2009). Crop production and road connectivity in Sub-Saharan Africa: A spatial analysis. Africa Infrastructure Country Diagnostic Working Paper 19. A publication of the World Bank.

Taiwo, A. and Kumi, F. (2013). An appraisal of road condition effect on rural transportation in Sekyere central district of the Ashanti Region of Ghana. Journal of Transportation Technologies, 3: 266-271.

Tunde, A. M. and Adeniji, E. E. (2012). Impact of road transport on agricultural development: A Nigerian example. Ethiopian Journal of Environmental Studies and Management, 5(3): 232238. use, distribution, and reproduction in any medium, provided the original work is cited appropriately. 